\title{
Acute Diarrheal Management in Adults: A Simulated Client Study at Community Pharmacies of Quetta City, Pakistan
}

\author{
Asad Khan', Qaiser Iqbal', Sajjad Haider ${ }^{1}$, Adnan Khalid ${ }^{2}$, Mohamed Azmi Hassali ${ }^{3}$, Fahad Saleem ${ }^{1, *}$ \\ ${ }^{1}$ Faculty of Pharmacy and Health Sciences, University of Balochistan, Quetta, Balochistan, PAKISTAN. \\ ${ }^{2}$ Department of Surgery, Combined Military Hospital, Quetta, Balochistan, PAKISTAN. \\ ${ }^{3}$ School of Pharmaceutical Sciences, Universiti Sains Malaysia, Penang, MALAYSIA.
}

Received: 21 December 2018;

Accepted: 12 February 2019

*Correspondence to:

Dr. Fahad Saleem,

Faculty of Pharmacy and Health Sciences,

University of Balochistan, Quetta, Balochistan

PAKISTAN.

Email:fahaduob@gmail.com

Copyright: (C) the author(s),publisher and licensee Indian Academy of Pharmacists. This is an open-access article distributed under the terms of the Creative Commons Attribution Non-Commercial License, which permits unrestricted non-commercial use, distribution, and reproduction in any medium, provided the original work is properly cited.

\begin{abstract}
Objective: By using a simulated client approach, we aimed to assess the management of acute diarrhea in adults at community pharmacies in Quetta City, Pakistan. Methods: This was a cross sectional, simulated client study. The study was carried out in Quetta, the provincial capital of Balochistan province, Pakistan. Community pharmacies located in the urban region with more than 100 clients per day were targeted for data collection. The simulated client presented himself at the community pharmacies seeking treatment for acute diarrhea with a pre-planned discussion protocol. SPSS v 21.0 was use for data analysis. Based on the objectives of the study, data was described descriptively as frequencies and percentages. Results: A total of 185 pharmacies qualified for the study as per inclusion criteria but data was available from $155 \mathrm{CPs}$ (83.7\%). The average working hours for the CPs were fourteen while qualified pharmacist was only present in fifteen $(9.6 \%)$ of the pharmacies. The consultation time at the pharmacies ranged from 1-4 mins with a mean of $2.37 \pm 0.535$ mins. Tablet metronidazole was the most frequent medicine dispensed $(78.1 \%)$ at the CPs. Dimenhydrinate was dispensed (41.3\%) followed by Oral Rehydration Solution (ORS) and tablet domperidone (35.5 and 25.8\%) respectively. Minimum cost of medicine dispensed ranged from 10 Pakistan Rupees (PKR) i.e. (0.086 USD) to 960 PKR i.e. (8.30 USD). Conclusion: The management of acute diarrhea failed to meet the standard anti-diarrheal treatment as proposed by the guidelines. Therefore, a substantial improvement of pharmacy practice at the community pharmacies is urgently needed.
\end{abstract}

Key words: Acute Diarrheal Management, Community Pharmacies, Quetta, Simulated Client Study.

\section{INTRODUCTION}

Acute diarrhea in adults is defined as an increased stool content or frequency that lasts for less than 14 days. ${ }^{[1]}$ Additionally, an abrupt onset of 3 or more loose or liquid stools above baseline in a $24 \mathrm{~h}$ period is also termed as acute diarrhea in adults. ${ }^{[2]}$ In clinical practice, although acute diarrhea is often related to viral gastroenteritis; increased travelling, co-morbidities and food borne infections are closely linked to bacteria-related acute diarrhea. ${ }^{[3]}$ Even though acute diarrhea is a commonly reported condition, The Global Burden of Disease Study reported 2.3 billion illnesses and 1.3 million deaths worldwide resulted from acute diarrhea in $2015 .{ }^{[4]}$ The study also highlighted acute diarrhea as the leading cause of death among all ages as well as a leading cause of Disability-Adjusted Life Year (DALY) because of its impact on adolescent and children. ${ }^{[4]}$ Although, the past few decades have seen multiple interventions in terms of diarrheal treatment and management, ${ }^{[5]}$ diarrheal mortality rates are still higher around the globe and have remained comparatively invariable during the past 2 decades ${ }^{\left[{ }^{6]}\right.}$ In the nutshell, diarrhea still remains as an avertable burden of disease, predominantly in the South Asian and sub-Saharan African regions. ${ }^{[4]}$

The treatment and management of acute diarrhea in the initial stages is relatively simple. ${ }^{[5]}$ For the very reason, it is a general observation that acute diarrhea is perceived as a normal condition. As the conditions worsen, patients initially prefer to consult a community pharmacy as it is the first point of contact for the management of common illnesses. ${ }^{[7]}$ The community pharmacy carries a strong attraction for the patients as they can get symptom-based care and advice without any professional charges. In addition, community pharmacy is easier to contact and most importantly require less time of consultation. ${ }^{[7,8]}$ Therefore, community pharmacies are valued for their prospective role in the management of common ailments including acute diarrhea around the globe ${ }^{[9,10]}$ However, it is to be noticed that management and treatment of such ailments involve apposite understanding of patient profile as well as guidelines to treatment. Consequently, the individual stationed at the community pharmacy requires adequate knowledge and skills for effective disease management that is rarely reported from developing countries. ${ }^{[11,12]}$

Inline to what is reported, community pharmacies are also the first port of call in any disease condition or ailment in Pakistan. However, opposite to what is reported from developed countries, community pharmacies in Pakistan are still involved in traditional dispensing of medicines. ${ }^{[13]}$ Community pharmacies follow a conventional business model and patient oriented activities are least reported in literature. ${ }^{[14]}$ In a nutshell, provision of community pharmacy services is not up to the standard in Pakistan. Additionally, community pharmacies in Pakistan are generally owned by nonpharmacist (businessmen) and there is a lack of qualified pharmacist practicing at community pharmacies. Therefore, it is hypothesized that majority of the individuals dispensing at the community pharmacies are unaware of treatment guidelines and quality use of medications for common ailments presented at their counters. This in return shapes into irrational practices hence leading to treatment complications, drug resistance and additional economic burden on the society. Therefore, to evaluate the practices of minor ailment management at community pharmacies in Pakistan, we planned a study by using a simulated 
Client Approach (SCA). The approach utilizes surveyors who act as patients to make furtive observations of health worker practices during consultations. ${ }^{[15]}$ The SCA is an excellent approach to assess the quality of health care delivery and identify areas for quality improvement. ${ }^{[16]}$ The method is also highly consistent both in terms of reliability and validity as it allows insight into actual transactions and experiences of customers in a real time environment. Furthermore, SCA is a adaptable tool that has been widely used in both lowincome and high-income settings to assess the actual practices of community pharmacies. ${ }^{[17]}$ Hence considering that acute diarrhea is a common aliment in a developing country like Pakistan, it is vital to understand how patients are managed at community pharmacies where such treatment is frequently sought. We therefore aimed to assess the management of acute diarrhea in adults at community pharmacies in Quetta city, Pakistan.

\section{MATERIALS AND METHODS}

\section{Methods}

Study design and settings

This was a cross sectional, simulated client study. The study was carried out in Quetta, the provincial capital and largest city of Balochistan province, Pakistan. Located in northern Balochistan near the Pakistan-Afghanistan border, Quetta is a trade and communication centre between the two countries. The city is near the Bolan Pass route which was once one of the major gateways from Central Asia to South Asia. Quetta has a population of nearly 2.3 million out of which 1.3 million has urban residency and the district has relatively better health indicators than the rest of the province. ${ }^{[18]}$

\section{Inclusion criteria}

Unfortunately, there is unavailability of the exact number of community pharmacies operating in Quetta city. However, as per information provided by the official portal of Government of Balochistan, more than 1000 community pharmacies are registered in Quetta district. ${ }^{[19]}$ For the current study, we targeted the community pharmacies located in the urban region with more than 100 clients per day. Those community pharmacies not fulfilling the inclusion criteria were excluded from data collection.

\section{Data collection and time frame}

Data was collected from May 2018 to October 2018. The first author was trained by the research team to present himself at the community pharmacies seeking treatment for acute diarrhea and hence presented himself as a Simulated Client (SC) as presented in Table 1. Because of the financial limitations, the $\mathrm{SC}$ was unable to purchase the medications that were dispensed during the consultation. However, the SC made it sure that he memorizes the medications and quantity that were dispensed for acute diarrhea. The SC later excused by mentioning lack of money and informed to return back with the required amount to purchase the medicine. Soon after the SC left the premises, he filled out a questionnaire and noted information regarding questions asked at the pharmacy, medicines dispensed and advice offered. Each pharmacy was visited once, unless it was closed and then a second visit was made before it was excluded.

\section{Ethical approval}

Faculty of Pharmacy and Health Sciences, University of Balochistan, Quetta approved the study. Because of the nature of the study, informed consent was not obtained as it would have revealed the objective of the study hence compromising the study design and its results.

\begin{tabular}{|c|c|}
\hline \multicolumn{2}{|c|}{$\begin{array}{l}\text { Table 1: Instructions to the SC for presenting the } \\
\text { complaints at the CPS. }\end{array}$} \\
\hline \multicolumn{2}{|c|}{ Chief complaint: Loose stools for three days } \\
\hline \multicolumn{2}{|c|}{$\begin{array}{l}\text { The SC approaches the community pharmacies ask for treatment. When asked with } \\
\text { questions, the following were responses at every pharmacy: }\end{array}$} \\
\hline \multicolumn{2}{|l|}{ Questions and answers } \\
\hline Since how long you have loose stools? & 3 days \\
\hline How many stools are passed a day? & 4-6 times \\
\hline Any blood in stool? & No \\
\hline Abdominal cramps and pain & Mild to moderate \\
\hline What did you eat? & Home cooked food \\
\hline Loss of appetite/nausea or vomiting? & Mild \\
\hline Have you used any medication? & No \\
\hline Have you seen a physician? & No \\
\hline Do you have a prescription? & No \\
\hline
\end{tabular}

\section{Data analysis}

SPSS v 21.0 was use for data analysis. Based on the objectives of the study, data was described descriptively as frequencies and percentages.

\section{RESULTS}

A total of 185 pharmacies qualified for the study as per inclusion criteria but data was available from $155 \mathrm{CPs}(83.7 \%)$ as the thirty pharmacies were closed despite the repeat visit. The average working hours for the CPs were fourteen while qualified pharmacist was only present in fifteen $(9.6 \%)$ of the pharmacies. The consultation time at the pharmacies ranged from 1-4 min with a mean of $2.37 \pm 0.535$ mins. No counseling was offered at the community pharmacies to the SC.

\section{Medicines dispensed during the SC visit}

The type of medicines that were offered during the $\mathrm{SC}$ visit is presented in Table 2. Tablet metronidazole was the most frequent medicine dispensed (78.1\%) at the CPs. Dimenhydrinate was dispensed (41.3\%) followed by Oral Rehydration Solution (ORS) and tablet domperidone (35.5 and 25.8\%) respectively. Ciprofloxacin was also dispensed in $20.6 \%$ while attapulgite was dispensed in $14.2 \%$ of the cases.

\section{Frequency of medications dispensed during the SC study}

Table 3 presents the frequency of medication dispensed during the SC visit. Metronidazole was dispensed to a minimum of 4 to maximum of 12 tablets. Tablet domperidone was dispensed with a minimum of 4 tablets to maximum of 10 with a range of 6 tablets. Oral Rehydration Salts were dispensed to a minimum of one sachet to maximum of 10 with a range of 9 sachets. Ciprofloxacin was ranged from minimum of 6 tablets to a maximum of 10 tablets while metronidazole + diloxanide ranged from a minimum of 6 to maximum of 16 tablets. Furthermore, minimum cost of medicine dispensed ranged from 10 Pakistan Rupees (PKR) i.e. (0.086 USD) to 960 PKR i.e. (8.30 USD).

\section{DISCUSSION}

Community pharmacies play a vital role in the provision of optimum healthcare services. This has become more imperative as the traditional role of dispensing of medication is heavily replaced by a patient-oriented 


\begin{tabular}{|c|c|c|}
\hline Medications & Frequency & Percentage \\
\hline $\begin{array}{l}\text { Metronidazole (tablet } 400 \mathrm{mg} \text { ) } \\
\text { Yes } \\
\text { No }\end{array}$ & $\begin{array}{l}121 \\
34\end{array}$ & $\begin{array}{l}78.1 \\
21.9\end{array}$ \\
\hline $\begin{array}{l}\text { Domperidone (tablet } 10 \mathrm{mg} \text { ) } \\
\text { Yes } \\
\text { No }\end{array}$ & $\begin{array}{l}40 \\
115\end{array}$ & $\begin{array}{l}25.8 \\
74.2\end{array}$ \\
\hline $\begin{array}{l}\text { Oral Rehydration Solution (sachet) } \\
\text { Yes } \\
\text { No }\end{array}$ & $\begin{array}{l}55 \\
100\end{array}$ & $\begin{array}{l}35.5 \\
64.5\end{array}$ \\
\hline $\begin{array}{l}\text { Ciprofloxacin (tablet } 500 \mathrm{mg} \text { ) } \\
\text { Yes } \\
\text { No }\end{array}$ & $\begin{array}{l}32 \\
123\end{array}$ & $\begin{array}{l}20.6 \\
79.4\end{array}$ \\
\hline $\begin{array}{l}\text { Attapulgite (tablet) } \\
\text { Yes } \\
\text { No }\end{array}$ & $\begin{array}{l}22 \\
133\end{array}$ & $\begin{array}{l}14.2 \\
85.8\end{array}$ \\
\hline $\begin{array}{l}\text { Dimenhydrinate (tablet) } \\
\text { Yes } \\
\text { No }\end{array}$ & $\begin{array}{l}64 \\
91\end{array}$ & $\begin{array}{l}41.3 \\
58.7\end{array}$ \\
\hline $\begin{array}{l}\text { Metronidazole+Diloxanide (tablet } 400 / 500 \mathrm{mg} \text { ) } \\
\text { Yes } \\
\text { No }\end{array}$ & $\begin{array}{l}27 \\
128\end{array}$ & $\begin{array}{l}17.4 \\
82.6\end{array}$ \\
\hline $\begin{array}{l}\text { Ofloxacin (tablet } 200 \mathrm{mg} \text { ) } \\
\text { Yes } \\
\text { No }\end{array}$ & $\begin{array}{l}6 \\
149\end{array}$ & $\begin{array}{l}3.9 \\
96.1\end{array}$ \\
\hline $\begin{array}{l}\text { Loperamide (tablet) } \\
\text { Yes } \\
\text { No }\end{array}$ & $\begin{array}{l}26 \\
129\end{array}$ & $\begin{array}{l}16.8 \\
83.2\end{array}$ \\
\hline $\begin{array}{l}\text { Multiviatamins (tablet) } \\
\text { Yes } \\
\text { No }\end{array}$ & $\begin{array}{l}16 \\
139\end{array}$ & $\begin{array}{l}10.3 \\
89.7\end{array}$ \\
\hline $\begin{array}{l}\text { Mebeverine (tablet) } \\
\text { Yes } \\
\text { No }\end{array}$ & $\begin{array}{l}20 \\
135\end{array}$ & $\begin{array}{l}12.9 \\
87.1\end{array}$ \\
\hline $\begin{array}{l}\text { Probiotics (tablet) } \\
\text { Yes } \\
\text { No }\end{array}$ & $\begin{array}{l}17 \\
138\end{array}$ & $\begin{array}{l}11.0 \\
89.0\end{array}$ \\
\hline
\end{tabular}

approach. Among the numerous responsibilities of community pharmacy, the far most important role is the provision and promotion of quality use of medicines. This ensures responsible medication use hence decreasing the overall cost of treatment both in terms of societal and economic measures. ${ }^{[20,21]}$ At the same time, medication adherence advice, risk evaluation and mitigation strategies enables the community pharmacists to act as an advisors to physicians and contribute directly in the decision making process. ${ }^{[2]}$ Our claim is evident in literature whereby the importance of community pharmacy was reported in emergency contraception, self-initiated aspirin treatment, referral for medical advice and smoking cessation therapies. ${ }^{[23]}$ Additionally, the access of reaching a community pharmacy is seriously preferred by public. ${ }^{[24]}$ An estimated 438 million health-related visits to a community pharmacy were reported compared to 340 million general physician consultations. ${ }^{[25]}$ Therefore, community pharmacies present an environment of confidence that advances wellbeing of the public by reducing costs and improvement in the overall quality of life. ${ }^{[2]}$

Keeping the emerging role of community pharmacies in mind, the current study was aimed to assess the management of acute diarrhea at community pharmacies of Quetta city, Pakistan. As per standard treatment guidelines of acute diarrheal management proposed by World Gastroenterology Organization, ${ }^{[6]}$ Oral Rehydration Therapy (ORT) is the treatment of choice. Parallel to the ORT, loperamide $(4-6 \mathrm{mg} / \mathrm{d})$ is the agent of choice for adults. However, loperamide should be discouraged in suspected inflammation which
Table 3: Frequency of medications dispensed during the simulated client study.

\begin{tabular}{|c|c|c|c|c|c|}
\hline 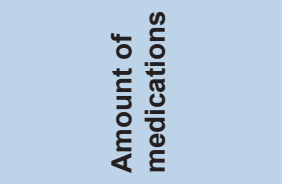 & 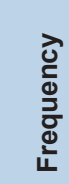 & 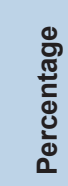 & 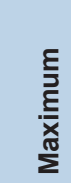 & 惡 & $\begin{array}{l}\stackrel{0}{\circ} \\
\frac{\mathbb{J}}{\mathbb{N}} \\
\text { வ }\end{array}$ \\
\hline $\begin{array}{l}\text { Metronidazole (tablet } \\
400 \mathrm{mg} \text { ) } \\
4 \\
6 \\
8 \\
10 \\
12\end{array}$ & $\begin{array}{l}3 \\
69 \\
2 \\
45 \\
2\end{array}$ & $\begin{array}{l}1.9 \\
44.5 \\
1.3 \\
29.0 \\
1.3\end{array}$ & 12 & 4 & 8 \\
\hline $\begin{array}{l}\text { Domperidone (tablet } \\
10 \mathrm{mg} \text { ) } \\
4 \\
6 \\
10\end{array}$ & $\begin{array}{l}6 \\
27 \\
8\end{array}$ & $\begin{array}{l}3.9 \\
17.4 \\
5.2\end{array}$ & 10 & 4 & 6 \\
\hline $\begin{array}{l}\text { Oral Rehydration Solution } \\
\text { (sachet) } \\
1 \\
2 \\
3 \\
4 \\
5 \\
6 \\
10\end{array}$ & $\begin{array}{l}1 \\
9 \\
16 \\
4 \\
8 \\
16 \\
1\end{array}$ & $\begin{array}{l}0.6 \\
5.8 \\
10.3 \\
2.6 \\
5.2 \\
10.3 \\
0.6\end{array}$ & 10 & 1 & 9 \\
\hline $\begin{array}{l}\text { Ciprofloxacin (tablet } \\
\mathbf{5 0 0} \mathbf{~ m g} \text { ) } \\
6 \\
10\end{array}$ & $\begin{array}{l}12 \\
20\end{array}$ & $\begin{array}{l}7.7 \\
12.9\end{array}$ & 10 & 6 & 4 \\
\hline $\begin{array}{l}\text { Attapulgite (tablet) } \\
6 \\
10\end{array}$ & $\begin{array}{l}16 \\
6\end{array}$ & $\begin{array}{l}10.3 \\
3.9\end{array}$ & 10 & 6 & 4 \\
\hline $\begin{array}{l}\text { Dimenhydrinate (tablet) } \\
2 \\
4 \\
5 \\
6 \\
10\end{array}$ & $\begin{array}{l}1 \\
1 \\
1 \\
46 \\
5\end{array}$ & $\begin{array}{l}0.6 \\
0.6 \\
0.6 \\
29.7 \\
9.7\end{array}$ & 10 & 2 & 8 \\
\hline $\begin{array}{l}\text { Metronidazole+ } \\
\text { Diloxanide (tablet 400/500 } \\
\mathbf{m g} \text { ) } \\
4 \\
6 \\
10 \\
16\end{array}$ & $\begin{array}{l}2 \\
12 \\
12 \\
1\end{array}$ & $\begin{array}{l}1.3 \\
7.7 \\
7.7 \\
0.6\end{array}$ & 16 & 4 & 12 \\
\hline $\begin{array}{l}\text { Ofloxacin (tablet } 200 \mathrm{mg} \text { ) } \\
6 \\
10\end{array}$ & $\begin{array}{l}3 \\
3\end{array}$ & $\begin{array}{l}1.9 \\
1.9\end{array}$ & 10 & 6 & 4 \\
\hline $\begin{array}{l}\text { Loperamide (tablet) } \\
2 \\
4 \\
6 \\
10\end{array}$ & $\begin{array}{l}1 \\
5 \\
16 \\
4\end{array}$ & $\begin{array}{l}0.6 \\
3.2 \\
10.3 \\
2.6\end{array}$ & 10 & 2 & 8 \\
\hline $\begin{array}{l}\text { Multiviatamins (tablet) } \\
30\end{array}$ & 16 & 10.3 & 30 & 30 & 0 \\
\hline $\begin{array}{l}\text { Mebeverine (tablet) } \\
4 \\
6 \\
10\end{array}$ & $\begin{array}{l}1 \\
13 \\
6\end{array}$ & $\begin{array}{l}0.6 \\
8.4 \\
3.9\end{array}$ & 10 & 4 & 6 \\
\hline $\begin{array}{l}\text { Probiotics (tablet) } \\
4 \\
5 \\
6 \\
8 \\
10\end{array}$ & $\begin{array}{l}3 \\
1 \\
10 \\
2 \\
1\end{array}$ & $\begin{array}{l}1.9 \\
0.6 \\
6.5 \\
1.3 \\
0.6\end{array}$ & 10 & 4 & 6 \\
\hline
\end{tabular}




\section{Khan, et al.: Acute Diarrheal Management in Adults}

can be sort out by significant abdominal pain or bloody diarrhea cases. The use of adsorbents such as kaolin, activated charcoal and attapulgite add to the cost of therapy, has minimal efficacy and hence should not be used in acute diarrhea. Ciprofloxacin is drug of choice in diarrheal cases of cholera, campylobacter and shigellosis, while metronidazole is indicated for the cases of giardiasis and invasive intestinal amebiasis. Probiotics have pronounced health benefits in human beings, however; verification is needed for the efficacy of each strain hence use in acute diarrhea depends upon proper laboratory investigation. Therefore, the use of probiotics in developing countries is not promoted due to lesser facilities in terms of diagnosis. ${ }^{\left[{ }^{6}\right.}$

In the current study, the most commonly dispensed drug was metronidazole (78.1\%). Ironically, ORS was observed in only $35.5 \%$ and loperamide in $16 \%$ of the entire cases. Almost $25 \%$ of the prescriptions contained domiperidone while $41.3 \%$ of the prescriptions had dimenhydrinate. In this SC study, we concluded that irrational therapy to manage $\mathrm{AD}$ was a common trend at community pharmacies of Quetta city because ORS and loperamide being first line therapeutic agents were not dispensed. Additionally, metronidazole and attapulgite with minimum efficacy and adding to the cost of therapy was observed. Furthermore, agents such as dimendyrinate, probiotics, mebeverine, multivitamins and domeperidone were also dispensed despite of their negligible role in managing acute diarrhea. Lack of performing the diagnostic procedures in order to sort out the exact etiology of diarrhea was again a major cause of irrational therapy. In this study none of the cases were sent for a diagnostic procedure and all of dispensed medications were based on empirical therapies. There was no trend of history taking, counseling and non-pharmacological advices despite of their prime importance in managing acute diarrhea. Overall management of acute diarrhea was suboptimal in this study.

The possible causes of this suboptimal therapy trends are multifold. Lack of qualified pharmacists at the community pharmacies is the prime cause. There are estimated 45,000-50,000 wholesale and retail drug outlets in Pakistan. However, there are only 8102 registered pharmacists present in the entire country. Therefore, most of these pharmacies are managed by non-professionals who lack adequate knowledge and do not possess any professional qualification that leads to irrational dispensing. ${ }^{[27]}$

Additionally, time of interaction with the SC was another important issue highlighted by the current study. Insufficient interaction time is a major hurdle in implementation of pharmaceutical care to patients attending community pharmacies. ${ }^{[28]}$ The trend of following conventional or classic therapies without updating oneself or taking a novel initiative in treating acute diarrhea is again a major cause of suboptimal therapy. Finally, profitability was reported as an influencing factor as operators of the community pharmacies preferred to dispense medications with high profitability such as probiotics and avoiding ORS and loperamide thus promoting irrational prescribing. The economic profile of this study was again questionable as the minimum cost of dispensing was Pakistan Rupees 10 (0.086 USD) while maximum was Pakistan Rupees 960 PKR (8.30 USD) with mean of Pakistan Rupees 176.87 (1.28 USD) indicating a huge variance in selection of medicines at the community pharmacies in Quetta city.

\section{CONCLUSION}

It was observed that management of acute diarrhea failed to meet the standard anti diarrheal management as proposed by the guidelines. Therefore, a substantial improvement of pharmacy practice at the community pharmacies is urgently needed. As majority of the community pharmacies are operated by non-professionals, the results can be generalized to the rest of the province as Quetta in the most advanced city of Balochistan. It is high time that policy makers should make sure about the availability of a qualified pharmacist at the community pharmacies. Furthermore, well designed professional education programs must be arranged to ensure continuous professional development of the pharmacists practicing at the community pharmacies.

\section{Study Limitations}

Because of financial limitations, we were unable to purchase medicines that were dispensed during the SC visit. Therefore, a recall bias is possible, however; the SC was trained appropriately to remember and memorize the medicines dispensed during his visit to the CPs. Nevertheless, a more thorough study with the purchase of actual medicine is recommended.

\section{ACKNOWLEDGEMENT}

The authors acknowledge the community pharmacies for their participation.

\section{CONFLICT OF INTEREST}

The authors declare no Conflict of Interest.

\section{ABBREVIATIONS}

DALY: Disability Adjusted Life Year; SCA: Simulated Client Approach; SC: Simulated Client; PKR: Pakistan Rupees; ORT: Oral Rehydration Therapy.

\section{REFERENCES}

1. Guerrant RL, Gilder TV, Steiner TS, Thielman NM, Slutsker L, Tauxe RV, et al. Practice guidelines for the management of infectious diarrhea. Clinical Infectious Diseases. 2001;32(3):331-51.

2. Riddle MS, DuPont HL, Connor BA. ACG clinical guideline: diagnosis, treatment and prevention of acute diarrheal infections in adults. The American Journal of Gastroenterology. 2016;111(5):602-22.

3. Wendy B, Andrew S. Acute diarrhea in adults. American Family Physician. 2014;89(3):180-9.

4. GBD Diarrhoeal Diseases Collaborators. Estimates of global, regional and national morbidity, mortality and aetiologies of diarrhoeal diseases: a systematic analysis for the Global Burden of Disease Study 2015. Lancet Infectious Diseases. 2017;17(9):909-48.

5. World Health Organization. The treatment of diarrhoea. 2005 [Available from: http:// apps.who.int/iris/bitstream/handle/10665/43209/9241593180.pdf?sequence=1].

6. Farthing M, Salam MA, Lindberg G, Dite P, Khalif I, Salazar-Lindo E, et al. Acute diarrhea in adults and children: a global perspective. Journal of Clinical Gastroenterology. 2013;47(1):12-20.

7. Diwan V, Sabde YD, Byström E, DeCosta A. Treatment of pediatric diarrhea: a simulated client study at private pharmacies of Ujjain, Madhya Pradesh, India. The Journal of Infection in Developing Countries. 2015;9(05):505-11.

8. Kamat VR, Nichter M. Pharmacies, self-medication and pharmaceutical marketing in Bombay, India. Social Science and Medicine. 1998;47(6):779-94.

9. Karim R, Ramdahin P, Boodoo J, Kochhar A, Pinto PL. Community pharmacists' knowledge and dispensing recommendations for treatment of acute diarrhoea in Trinidad, West Indies. International Journal of Clinical Practice. 2004;58(3):264-7.

10. Ogbo PU, Aina BA, Aderemi-Williams RI. Management of acute diarrhea in children by community pharmacists in Lagos, Nigeria. Pharmacy Practice. 2014;12(1):376.

11. Ross-Degnan D, Soumerai SB, Goel PK, Bates J, Makhulo J, Dondi N, et al. The impact of face-to-face educational outreach on diarrhoea treatment in pharmacies. Health Policy and Planning. 1996;11(3):308-18.

12. Nsimba SED. Assessing the performance, practices and roles of drug sellers/ dispensers and mothers'/guardians' behaviour for common childhood conditions in Kibaha district, Tanzania. Tropical Doctor. 2007;37(4):197-201.

13. Hashmi FK, Hassali MA, Khalid A, Saleem F, Aljadhey H, Bashaar M. A qualitative study exploring perceptions and attitudes of community pharmacists about extended pharmacy services in Lahore, Pakistan. BMC Health Services Research. 2017;17(1):500.

14. Hussain A, Malik M, Toklu HZ. A literature review: pharmaceutical care an evolving role at community pharmacies in Pakistan. Pharmacology and Pharmacy. 2013;4(05):425-30. 
15. Rowe AK, Onikpo F, Lama M, Deming MS. Evaluating health worker performance in Benin using the simulated client method with real children. Implementation Science. 2012;7(1):95

16. Fitzpatrick A, Tumlinson K. Strategies for optimal implementation of simulated clients for measuring quality of care in low and middle-income countries. Global Health: Science and Practice. 2017;5(1):108-14.

17. Watson MC, Norris P, Granas A. A systematic review of the use of simulated patients and pharmacy practice research. International Journal of Pharmacy Practice. 2006;14(2):83-93.

18. Pakistan Bureau of Statistics. Province wise provisional results of census. 2019. [Available from: zttp://www.pbs.gov.pk/sites/default/files/PAKISTAN\%20 TEHSIL\%20WISE\%20FOR\%20WEB\%20CENSUS_2017.pdf].

19. Government of Balochistan. Social infrastructure. 2019. [Available from: http:// www.balochistan.gov.pk/index.php?option=com_content $\&$ view $=$ article $\&$ id $=839$ \&ltemid=1087].

20. Munroe WP, Kunz K, Dalmady-Israel C, Potter L, Schonfeld WH. Economic evaluation of pharmacist involvement in disease management in a community pharmacy setting. Clinical Therapeutics. 1997;19(1):113-23.

21. Birenbaum A. Reprofessionalization in pharmacy. Social Science and Medicine. 1982;16(8):871-8.
22. Azhar S, Hassali MA, Ibrahim MIM, Ahmad M, Masood I, Shafie AA. The role of pharmacists in developing countries: the current scenario in Pakistan. Human Resources for Health. 2009;7(1):54

23. Anderson C, Blenkinsopp A, Armstrong M. The contribution of community pharmacy to improving the public's health. Report 2, Evidence from the UK non peer-reviewed literature 1990-2002. PharmacyHealthLink and the Royal Pharmaceutical Society of Great Britain. 2003.

24. Jesson J, Bissell P. Public health and pharmacy: a critical review. Critical Public Health. 2006;16(2):159-69.

25. National Health Service. Transforming urgent and emergency care services in England. 2013. [Available from: https://www.nhs.uk/NHSEngland/keogh-review/ Documents/UECR.Ph1Report.FV.pdf].

26. Terry S. Community pharmacists play key role in improving medication safety. Pharmacy Times. 2010. [Available from: http://www.pharmacytimes.com/ publications/issue/2010/november2010/communitypharmacists_medsafety].

27. Haq NU, Riaz S, Nasim A. Pharmacy without pharmacist: Body without soul. Archives of Pharmacy Practice. 2017;8(2):84.

28. Dunlop JA, Shaw JP. Community pharmacists' perspectives on pharmaceutical care implementation in New Zealand. Pharmacy World and Science. 2002;24(6):224-30.

Cite this article as: Khan A, Iqbal Q, Haider S, Khalid A, Hassali MA, Saleem F. Acute Diarrheal Management in Adults: A Simulated Client Study at Community Pharmacies of Quetta City, Pakistan. J Pharm Pract Community Med. 2019;5(1):13-7. 